\title{
Türk Fotoğrafında Yeni Bir Soluk: Deneysel/Kurgu Fotoğraf*
}

\author{
Işık SEZER **, Özlem DEMİRCAN***
}

Özet

Makale kapsamında 1980 -1995 döneminde Türk fotoğrafında etkili olan deneysel/kurgu fotoğraf ifade biçimi, geleneksel karanlık oda teknikleri ile yaratılan örnek vizyonlar çerçevesinde incelenmiştir. Avrupa'da eğitim gören Türk fotoğrafçılarının Batı görüntü üretim kriterlerini temel alan işleri sayesinde ülkemizde fotoğraf sanatı, bireysellik, dışavurum vb. teknik ve kuramsal konular üzerinden tartışılmaya başlanmıştır. Bahsi geçen dönemde üretilen deneysel/kurgu fotoğraflar, başlangıcından itibaren Türk fotoğrafına hâkim olan ‘var olan gerçekliği saptama’ tavrına alternatiftir. Bu süreci hazırlayan, üniversitelerde fotoğraf eğitiminin başlaması, dernekleşme, yayın sayısının artması vb. etkenler bu makalede incelenen başlıca konulardır. Türk fotoğrafında avangard ve postmodernist önermeler taşıyan sınırlı sayıdaki bu fotoğraflar, günümüz Türk fotoğrafının oluşumunda temel teşkil etmektedirler.

Anahtar Sözcůkler: Deneysel Fotoğraf, Kurgu Fotoğraf, Türk Fotoğraf Tarihi.

\section{A New Breath in Turkish Photography: Experimental and Fiction Photography}

\section{Abstract}

In scope of this paper, the style of experimental/fiction photography, which has been influential during the period of $1980-1995$ in Turkish photography, is examined through the visions created by traditional darkroom techniques. Thanks to the works of Turkish photographers who were educated abroad, art of photography has started to be evaluated through Western technical and theoretical aspects which are based on individualist and expressionist production criteria.

Experimental/fiction photography, which is created in that period, is an alternative to the concept of 'determination of existing reality' dominating the Turkish photography from its origins to the present time. The main themes that are investigated in this paper are the beginning of photography education in universities, boosting of associations and increase of number of publications, etc. These limited photographs conveying avant-garde and postmodernist approaches, form the basis of today's Turkish photography. 


\section{Giriş}

1980-1995 yılları, Türk fotoğrafında kurgu fotoğraf veya deneysel fotoğraf olarak adlandırılan bir akımın, yeni bir görsel ifade biçiminin etkin olduğu yıllardır. Türk fotoğrafına hâkim olan 'var olan gerçekliği saptama' tavrına alternatif olan deneysel fotoğrafta, görsel tasarım ve karanlık oda teknikleri, sanatçının duygu ve düşüncelerinin ifade aracına dönüşmüştür. Bireyselliğin dışavurumu olan yalın kompozisyonlu fotoğraflarda, fotomontaj, kolaj, solarizasyon, ton indirgeme, boyama, farklı filtre efektleri vb. karanlık oda baskı teknikleri ve grafik unsurlar, estetik tavrın temeli olarak kullanılmıştır. Fotoğrafların kurgu içeriğinde genelde özlem, kıskançlık, sevgi vb. evrensel duygu değerlerinin sembolik anlatımı hâkimdir.

Seyit Ali Ak (1989: 28), “1980 kuşağı” olarak adlandırdığı dönemin fotoğrafçılarını "sosyal, ekonomik durumu belli bir çizginin üzerinde, ticari alanlardan elde ettikleri kazancı sanatsal uğraşlarına aktaran, uzun soluklu bir çalışma temposu tutturan ve ürünlerini yarışmalar, sergiler, yayınlar yoluyla her fırsatta izleyiciye ulaştırma çabası içinde olan kimseler" olarak tanımlamaktadır.

Yurtdışı eğitim deneyimlerinin sonucu olarak geliştirdikleri vizyonları ile Şahin Kaygun deneysel - kurgu ve Ahmet Öner Gezgin'in kurgu ağırlıklı öncü vizyonları, Türk fotoğrafına yeni önermeler sunmuştur. Bu fotoğraflar, Avrupa ve Amerika fotoğraf sanatının gelişimi ile karşılaştırıldığında, örneğin avangard sanat akımlarını yaşamadan, teknik estetik tartışmalardan uzak, sürekli kendini tekrarlamakta olan Türk fotoğrafı açısından devrim niteliğindedir. Sanatçılara ve yapitlarına gösterilen olumlu / olumsuz eleştiriler sonucu, Türk fotoğrafçıları, fotoğraf sanatı kavramını, estetik, yaratıcılık, birey olgusu vb. açılardan çok yönlü bir biçimde tartışmaya başlamışlardır. Konuya farklı bir açıdan bakılacak olursa, bu yeni yaklaşım ile Türk fotoğrafı kendi dar kalıplarından sıyrılarak dünya fotoğraf sanatını tanımaya başlamıştır.

Sanatçıların vizyonları ve etkileşimleri ele alınmadan önce, bu anlatım dilinin ortaya çıktığı zaman dilimini hazırlayan sosyal ve kültürel boyutun gözden geçirilmesi gerekmektedir.

\section{Dönemi Hazırlayan Koşullar}

\subsection{Fotoğraf Eğitiminin Üniversitelerde Yer alması}

Yüksek öğretim kurumlarında 'Fotoğraf' dersi, Şinasi Barutçu'nun çabaları ile başlamıştır. Devlet bursu ile gittiği Almanya'da Köln 'İ̧̧ Muallim Mektebi' ve Bonn 'Pedagoji Akademisi'ni 1932'de bitirerek yurda dönmüştür. Yazı, Grafik Sanatlar ve Fotoğrafi öğretmeni olarak atandığı Ankara Gazi Terbiye Enstitüsü'nde Grafik dersleri kapsamında fotoğraf eğitimi resmen başlamıştır (http://sinasibarutcu.blogspot.com.tr).

İkinci Dünya Savaşı sürecinde kesintiye uğrayan fotoğraf eğitimi, Ankara'da 'Halkevi Foto Kursu', 1950'de Halkevleri kapatılana dek sürmüştür (Zeyrek,2006:120). Fotoğrafçılık 1957'de kurulan Devlet Tatbiki Güzel Sanatlar Yüksek Okulu, Grafik Sanatlar Bölümü'nde ders olarak okutulmuştur (Ertan, 2005: 27). Buradan 1963 yılında mezun olan Güler Ertan, 1964 yılında Grafik Bölümü’nde fotoğraf asistanı olarak çalışmaya başlamıştır. 1968'de Avusturya Devlet Bursu'nu kazanarak Viyana'da Höhere Graphische Bundeslehr und Versuchsanstalt okulunda renkli fotoğraf eğitimi alan Ertan, Devlet Tatbiki Güzel Sanatlar Yüksek Okulu'nda fotoğraf teknikleri ve grafik sanatının bütünleşmesinde ve yeni anlatım biçimlerinin şekillendirilmesinde öncü isimlerden biridir (Ertan, 1977). Ertan'ın öğrencilerinden biri de Şahin Kaygun'dur.

Devlet Güzel Sanatlar Akademisi'nden çoğunlukla devlet bursu ile Fransa, Almanya, Avusturya'ya giden sanatçılara karşın, 1960 sonrası çoğunlukla New York’a lisans ve yüksek lisans eğitimine gidilmiştir:

1970'lerde sanat alanında '1968 Kuşağı' olarak adlandırılan Mehmet Güleryüz, Alaettin Aksoy, Burhan Uğur, Neş'e Erdok, Komet, Utku Varlık'ın figüratif çalışmaları ile bireysel ifadelere geniş bir alan tanıyarak çok özgün işlerin ortaya çıkmasına yardımcı olduğu görülür. Öznel bakış açısının egemen olduğu resimlerinde sanatçılar, kendilerinden önceki figüratif ressamlardan farklı olarak figüre, bireysel bakış açısı ile yaklaşmışlardır. (Duben-Yıldız, 2008: 23).

Adı geçen sanatçıların sergilerinin çoğunun Devlet Güzel Sanatlar Akademisi'nde açılması, disiplinler arası iletişimin güçlenmesini sağlamıştır. 
İstanbul Devlet Güzel Sanatlar Akademisi, Yüksek Dekoratif Sanatlar Bölüm Başkanı Prof. Erdoğan Aksel başkanlığında, Cafer Türkmen, Ersin Alok, Gültekin Çizgen, Ahmet Öner Gezgin, İnal Göral, Mehmet Bayhan, Reha Günay, Sami Güner ve Şahin Kaygun'dan oluşan ön kurul, Fotoğraf Okulu'nun kuruluş çalışmalarına başlamıştır (www.arsivfotoritim.com/yazi/ahmet-oner-gezgin). 1978'de kurulan Fotoğraf Enstitüsü, “1982'de Yüksek Öğretim Kanunu ile akademilere getirilen yeni kimlik sonucunda IDGSA Mimar Sinan Üniversitesi'ne dönüşmüş, Fotoğraf Enstitüsü de Güzel Sanatlar Fakültesi, Sahne ve Görüntü Sanatları Bölümü’ne bağlanmış ve Fotoğraf Anasanat Dalı adını almıştır. 1994 yılında ise Sanat Fotoğrafı, Tanıtım Fotoğrafı ve Belgesel Fotoğraf Sanat dallarını barındıran Fotoğraf Bölümü’ne dönüştürülmüştür." (www.msgsu.edu.tr).

\subsection{Fotoğraf Kulüpleri ve Dernekler}

1973 yılında kurulan Boğaziçi Üniversitesi Fotoğraf Kulübü (BÜFK), bir üniversitede kurulmuş olan ilk fotoğraf kulübüdür ve büyük ilgi ile karşılanmıştır. BüFK, gençler arasında fotoğrafın tanınması ve yaygınlaşmasında önemli bir merkez olmuştur: "1970-1972 yılları arasında amatör fotoğrafçılıkla ilgilenen meraklılar ya kendi imkânları ile ya da fizik ve kimya mühendisliği bölümü laboratuarlarındaki karanlık odalardan bölüm yetkililerinden izin alarak yararlanabiliyorlardı." (Yeni Fotoğraf, 1977: 25-28).

BüFK'ya benzer, 1977'de gerek amatör gerek profesyonel, çok sayıda fotoğrafçıyı bir araya getiren 'Fotos', Şahin Kaygun'un çabaları ile kurulmuştur. 1977 yılının başında, 'Türk Fotoğraf sanatçılarının tümünü bir çatı altında toplamak, sorunlara çok daha güçlü bir ses olarak karşı koymak ve çözüm aramak amacını' taşıyan 'Fotos' adlı bu derneğin kurucu üyeleri, Şahin Kaygun, Ersin Alok, Gülnur Sözmen, Suat Ataç, Hasan Kurbanoğlu, Ahmet Çetinkaya, Handan Özalanç, Güler Ertan ve Meral Kaygun'dur (Yeni Fotoğraf, 1979: 32-34). Düzenli aralıklar ile toplanarak oluşturulan tartışma platformlarında, fotoğrafçının telif haklarından Türkiye'de fotoğrafın gelişim sürecine kadar pek çok konu ele alınarak, varılan sonuçlar Yeni Fotoğraf dergisi vb. kaynaklar aracılığı ile paylaşılmıştır.

Türk fotoğrafının gelişiminde ve yaygınlaşmasında bireysel çabaların yanında dernekleşme de önemli bir yere sahiptir. TAFK (Türkiye Amatör Foto Kulübü, kuruluş:
1949), TAFK (Trabzon Amatör Foto Kulübü, kuruluş: 1959) ve İFSAK (İstanbul Fotoğraf ve Sinema Amatörleri Derneği, kuruluş: 1959), ilk kurulan amatör fotoğraf dernekleridir. 1977 yılında kurulan AFSAD (Ankara Fotoğraf Sanatçıları Derneği), 1979 yılında AFAD (Adana Fotoğraf Amatörleri Derneği) ve FOTOS elbirliği ile fotoğrafın gelişimine ve yaygınlaşmasına hizmet için sergi, panel, söyleşi vb. etkinlikleri düzenlemeye, eğitim programları yapmaya başlamışlardır ( http://www.tfsf.org.tr)

\subsection{Dergiler ve Fotoğraf Yıllıkları}

Şakir Eczacıbaşı'nın (1929-2010) girişimleri ile 1968 yılında yayınlanmaya başlayan 'Eczacıbaşı Renkli Fotoğraf Yıllıkları', her yıl belirlenen konu başlıkları (örneğin, Evler 1969, Anıtlar 1970, Sular 1971 vb.) ile Türk fotoğrafçılarının çalışmalarının bir araya getirildiği birer arşiv niteliğindedir (fotoritim, 2010).

1976 yılında ilk sayısı çıkan aylık 'Yeni Fotoğraf' dergisinin sahibi ve yazı işleri sorumlusu Engin Çizgen idi; danışma kurulu üyeleri ise Ara Güler, Gültekin Çizgen, Ersin Alok, Ozan Sağdıç, Reha Günay'dan oluşmaktaydı. Bu dergi, fotoğrafa ilişkin teknik bilgiler, Türkiye'deki fotoğraf etkinlik haberleri, yarışma haberleri, eleştiri yazıları ve portfolyo sunumları ile dönemin fotoğrafçıları için önemli bir kaynak niteliğinde olmuştur (Özdal, 2009: 122-132). Yeni Fotoğraf dergisi 46. Sayısında, basım, dağıtım vb. güçlükleri nedeniyle yayın hayatına son vermiştir.

AFSAD yayını olan 'Fotoğraf' dergisi ilk kez Kasım 1978 'de çıkmaya başlamış, yayını kesintilere uğrasa da varlığını korumuştur (afsad). 1988 Nisan ayında, aylık olarak yayın hayatına başlayan 'REFO Fotoğraf Sanatı Dergisi', 1991 yılında kapanmıştır (halimkulaksiz). Dergi baskı kalitesi ile ayrıcalıklı bir yere sahiptir.

Dergi sayısının çoğalması ve yurt geneline yaygınlaşması, fotoğraf kültürünün gelişmesinde ve ortak görsel hafızanın oluşmasında etkili olmuştur.

\section{12 Eylül 1980 Darbesi ve Sanata Etkileri}

27 Mayıs 1961 ihtilali, 12 Mart 1970 askeri muhtırası ve sonrasında ülke genelinde yaşanan iç terör ortamı, 1980 darbesini hazırlamıştır. 12 Eylül 1980 darbesi ile “Türkiye'nin kültürel ve politik tarihinde keskin bir kayma meydana gelmiştir. 24 Ocak 1980 kararları ile dışa açılma, 
kamusalın daraltılması ve dünya piyasalarına eklemlenme süreci" başlamıştır. Darbe sonrası bütün sivil toplum kuruluşları ve dernekler kapatılmış, (23.677 adet) başta eğitim kurumları ve basın olmak üzere toplumda çok büyük bir tasfiye gerçekleştirilmiştir. Binlerce kişi hapishanelere atılırken binlerce aydın, siyasi mülteci olarak yurt dışına çıkmıştır ( Oktay,2012). Beral Madra’ya göre,

1960'ların ve 70'lerin yalıtılmışlığı sona ermiş, sanatçılar ve aydınlar zamanı yaşamaktan kaçamaz duruma gelmiştir. Türkiye'deki zaman ile Türkiye dışındaki zaman artık aynıdır. Sanat/kültür altyapılarındaki zayıflılar, modernizm ve post-modernizm ayrımı ile iletişim ağının yarattığı eşzamanlılık birbirleriyle çatışmaktadır. 80’li yıllardaki değişim klasik modernden kaynaklanan yeni bir dil, yeni bir üslup değildir. Toplumsal, kültürel, siyasal sorunların doğurduğu yeni bir durum değerlendirmesinin sonucudur. Büyük, küresel, çokuluslu ve merkezsizleşen bir iletişim ağının varlığı ve bu ağın karmaşık yapısını algılama sürecine giren yeni bir bilincin varlığı söz konusudur. Sanatçı bu iletişim ağının algılanmasında bir aracı olmak gibi bir işlevi üstlenmiştir... Türkiye'de Sanat ve kültürün durumu, $70^{\prime} l i$ yılların sonunda ve $80^{\prime} l i$ yılların başında bazı önemli açık oturum ve sempozyumlarda ele alınmıştır. Bunlardan ilki Ekim, 1977'de IDGSA'nın 1. Sanat Bayramı kapsamında düzenlediği '2000 Yılına Doğru Sanatlar' başlıklı geniş katılımlı sempozyumdur. Bu sempozyumda sanatın geleceği, sanat ve toplum ilişkileri, sanat eğitimi konularında 37 bildiri verilmiştir. Sempozyum bir kitapla belgelenmiştir (Zürcher, 1996). Bunu 1979 yılında yapılan 'Türkiye'de Sanat Eğitimi' sempozyumu izlemiştir. 1983 ve 1984 'de üç önemli açık oturum yapılmıştır: Marmara Ünversitesi’nin düzelediği ‘İnsan-Sanat Çevre' sempozyumu, Galeriler Sempozyumu ve Mimar Sinan Üniversitesi'nin düzenlediği Müzecilik ve Koleksiyonculuk açık oturumu. 1985'de MSü'nün 5. Istanbul Sanat Bayramı çerçevesinde 'Sanat ve Gençlik' sempozyumunda gençliğin yaratma sorunu, sanatçıların gençlik yapıtları ve gençliğin sanat izleyiciliği ele alınmıştır. (www.beralmadra.net ).

1980 darbesi ile sakıncalı bulunularak kapatılan İF-
SAK, Mehmet Bayhan'ın girişimleriyle 1981'de faaliyete geçmiştir (Ertuğ, 2013: 130). Faaliyetleri durdurulan AFSAD da, 1981 başlarında tekrar çalışmaya başlamıştır (Ün, 2015). Yurt genelinde fotoğraf derneklerinin kurulumu ise hız kazanmıştır. 1980 ve sonrasında yurt genelinde kurulan dernekler sırasıyla EFOT (Edirne Fotoğraf Sanatı Derneği, kuruluş: 1980); KASK (Kocaeli Fotoğraf Sanatı Derneği, kuruluş: 1980); FOTOGEN (Fotoğraf Sanatı Derneği, kuruluş: 1985); İFOD (İzmir Fotoğraf Sanatı Derneği, kuruluş: 1986); BUFSAD (Bursa Fotoğraf Sanatı Derneği, kuruluş: 1986); MFD (Mersin Fotoğraf Derneği, kuruluş: 1987); FOTOFORUM (Trabzon Fotoğraf Sanatı Derneği, kuruluş: 1987); ANFAD (Antalya Fotoğraf ve Sinema Amatörleri Derneği, kuruluş: 1988); GAFSAD'dır (Gaziantep Fotoğraf Sanatı Derneği, kuruluş: 1989). Bu dernekler sayesinde fotoğrafçılı̆̆ımız geniş kitlelere ulaşmaya başlamıştır.

Fotoğraf alanındaki önemli etkinliklerden biri de, ilk kez 1983 yılında düzenlenen 1. Devlet Fotoğraf Yarışması'dır (sonuçları: 1.Cengiz Karlıova, 2.Ahmet Öner Gezgin, 3.Nevzat Çakır'dır; Mansiyon; Nuri Bilge Ceylan ve Mustafa Kocabaşı'na verilmiştir.) (Fotoğraf Dergisi, 1984: 3-7). Türk fotoğrafının geleneksel görüntüleme tavrı sosyal belgeci fotoğraf anlayışı ile kurgu/deneysel fotoğraf çalışmalarının bir arada değerlendirilmesi olumlu bir tavırdır. 1984 FIAP Renkli Baskı Bienali'nin 12.'si Türkiye'de İFSAK'ın girişimleri ile düzenlenmiştir. Bu etkinlik Türkiye'de renkli baskının gelişmişliğinin bir göstergesidir. Ayrıca yabancı fotoğrafçıların vizyonlarının tanınması bakımından önemli bir olaydır (Fotoğraf Dergisi,1984: 9).

\section{Deneysel / Kurgu Fotoğrafın Öncüleri}

Türk fotoğrafında, fotoğrafın bireysel bir dışavurum aracı olduğu, diğer sanat disiplinleri ile etkileşimleri ilk kez Şahin Kaygun (1951-1993) ve Ahmet Öner Gezgin'in (1948) çalışmaları ile gündeme gelmiştir. Kaygun, fotomontaj tekniğinin yanı sıra karanlık oda dönüştürme yöntemlerini de kullanarak fotoğraflarında zengin bir anlatım dili yaratmıştır. Gezgin'in vizyonunda ise fotomontaj tekniği kullanılarak oluşturulmuş anlam katmanları ön plandadır. Türk fotoğrafının tarihsel gelişiminde yaşanmamış olan avandgard sanat akımları ve kavramsal tartışmaların eksikliği göz önünde bulundurulduğunda, adı geçen sanatçıların vizyonlarının önemi netleşmektedir. "Türkiye'de seksenli 
yıllar, modern ve postmodern sanat pratiklerinin birlikte var olduğu bir dönemdir” (Duben-Yıldız, 2008: 24) ve Türk fotoğrafçıları için yeni ufuklar açmıştır.

1972 yılında Devlet Tatbiki Güzel Sanatlar Yüksek Okulu, Grafik Bölümü'nden mezun olan Kaygun, 19731976 sürecinde 400 yerli ve yabancı sanatçının fotoğraflarından oluşan 'Sanat İnsanları' serisini tamamlamıştır (www.fotograf.net). 1978'de sergilenen 'Sanat İnsanları' çalışması ile 1980 yılında, Avusturya hükümetinin davetlisi olarak Salzburg Uluslararası Yaz Akademisi'ne katılmıştır. Aynı yıl başladığı polaroid çalışmalarını 1984 yılında sergilemeye başlamış ve çalışmaları ile dünyanın en iyi on polaroid sanatçısı arasında yer almıştır. Çalışmalarında polaroid materyalini boyama, kazıma, ısıtma vb. yöntemlerle, teknik sınırları zorlayarak yeni bir görsel anlatım dili geliştirmiştir(İstanbul modern:2015). “Ara Güler, samimiyetini ve sanatın ağırlığını, Şahin Kaygun ile yaptığı bir söyleşi sırasında 'sen, fotoğraf tekniğini kullanarak sanat yapıyorsun. Örneğin senin son sergin (Polaroid Sergileri) fotoğraf değil bence, sanat. Yani çok daha önemli’ sözleriyle ortaya koymakta ve aslında fotoğrafın bir imge olarak gücünü de işaret etmekteydi.” (ün, 1995).

1984 - 1987 yılları arasında sinemada sanat yönetmenliği ve yönetmenlik yaptığ 1 'Dul Bir Kadın' (1984), ‘Adı Vasfiye’ (1985), ‘Ah Belinda’ (1986), ‘Anayurt Oteli’ (1987) ve kendi yönettiği ‘Afife Jale' (1987) ve ‘Dolunay’ (1987) (www.fotograf.net) Türk sinemasının kült filmleri arasındadır. Bu dönemde, eş zamanlı sürdürdüğü siyah beyaz baskılarda uyguladığı boyama, kazıma, fotomontaj, solarizasyon, kolaj tekniklerindeki ince işçilik ve iç dünyasının dışavurumundaki coşku, sanatçının imzası olur.

Kaygun, sanat anlayışını ve fotoğraflarını şu şekilde tanımlamıştır:

Beni tam olarak anlatan fotoğraflar değil. Ben, fotoğraflarımda kendi kurduğum dünyaların yer almasını istiyorum. Bir figür ya da nesne benim fotoğraflarımda yer alacaksa benim istediğim yerde, renkte ya da biçimde yer almalı. İlginç bir olayı saptamak ve yansıtmak yerine kafamdaki bir düşünceyi fotoğrafla anlatmak bana daha yakın geliyor.” (Dural-Şener, 2015: 15).

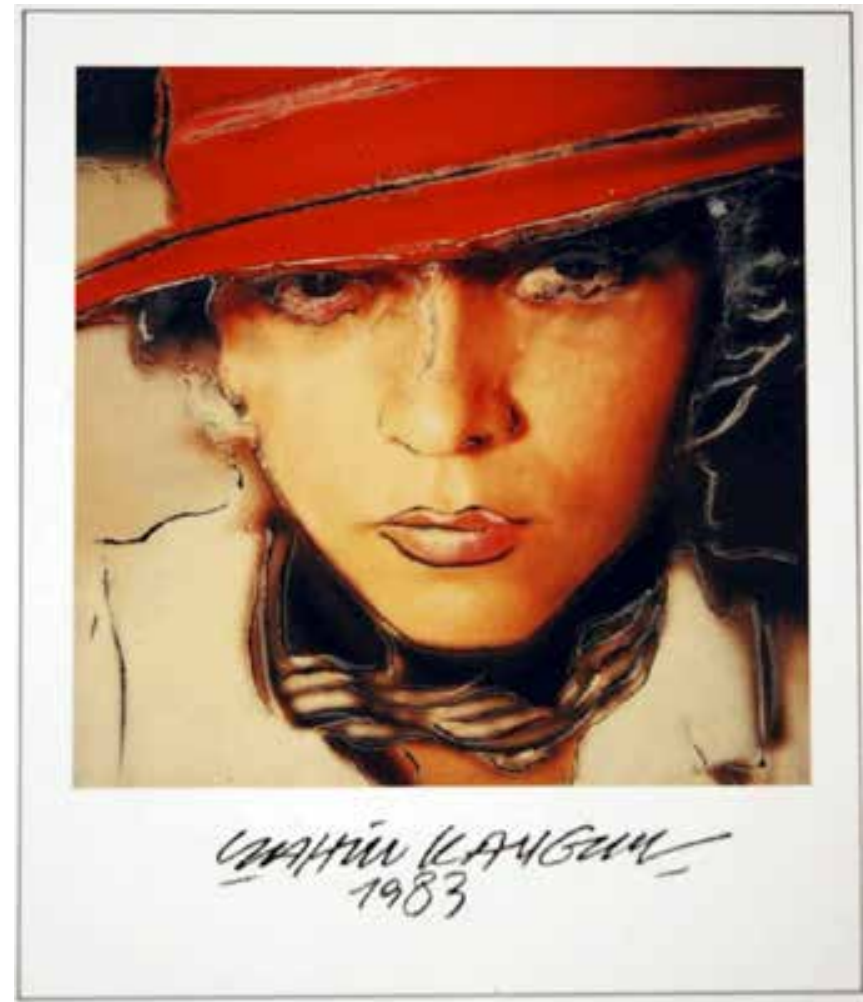

Fotoğraf.1 Şahin Kaygun, 1983

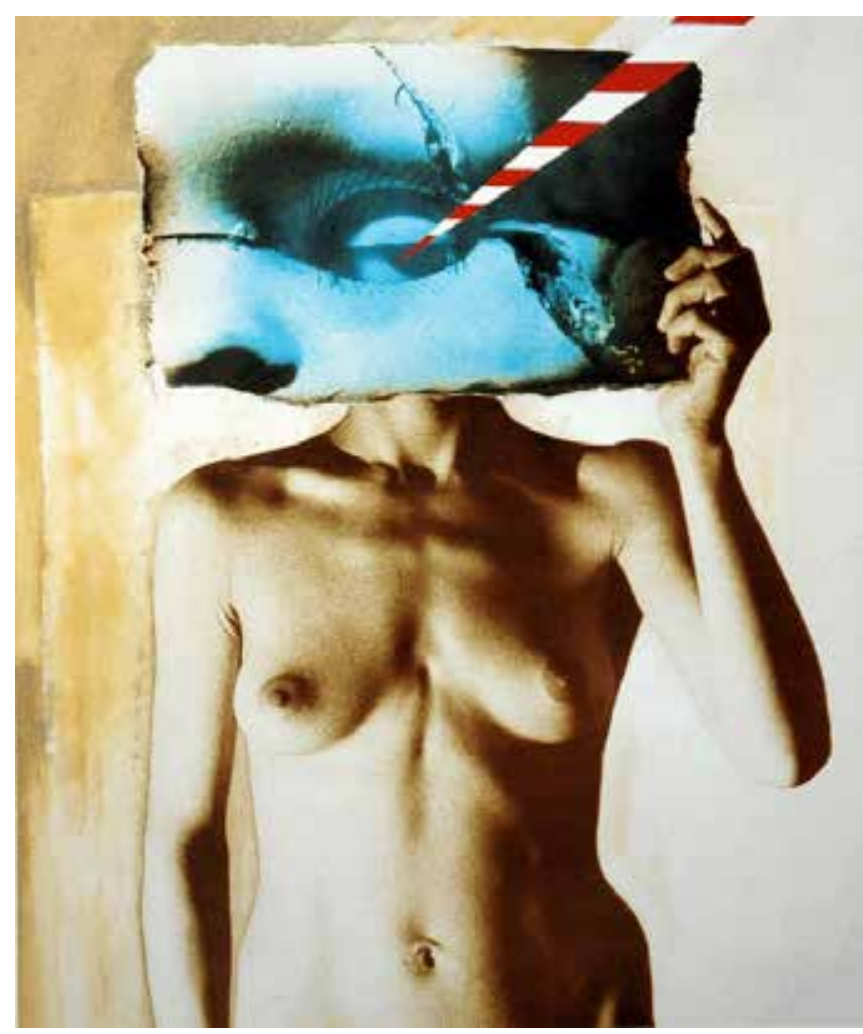

Fotoğraf 2. Şahin Kaygun, 'Genç Bir Kadının Günlüğünden’, 1984 
Kaygun'un, 1990-91 yıllarında üç büyük şehirde aynı anda açtığı 'Eski Zaman Denizlerinde' sergileri, arkeoloji, mitoloji, resim, fotoğraf ve edebiyat gibi sanat disiplinlerine yaptığı teknik ve estetik göndermeler sebebiyle postmodernizm çerçevesinde değerlendirilmelidir.

Şahin Kaygun'un büyük bir duyarlılıkla oluşturduğu, isimlendirerek (Genç Bir Kadının Günlüğü 1984 vb.) tanımladığı fotoğrafları, dönemin haber-belge fotoğraf anlayışının çok ötesinde disiplinler arası yeni önermelerle yüklüdür.

Şahin Kaygun'un vizyonunu referans alan ve özgün yorumları ile dikkat çeken ilk sanatçılardan Tahir ün (1960), 1974'de başladığı fotoğraf çalışmalarını 1978'de AFSAD'a üye olarak sürdürmüştür. Tahir ün'ün 'Değişiklik Anlarr' (Moments of Revulision) (1986) polaroid serisi, sanatçının iç dünyasını yansıtırken, çoklu ve parçalı komposizyonları ile dinamik bir anlatım diline sahiptir (tahirun.com). 1985-1989 döneminde gerçekleştirdiği ‘Düşlenmiş Manzaralar'(1988) serisi, çekim sırasında farklı filtre kullanımı ve baskı esnasında yapılan müdahalelerle dönüştürülmüş doğa fotoğraflarından oluşmaktadır (http://www.tahirun. com). Ün (1990), çalışmasının ana fikrini, "Bana göre özgürlüğün erdemi bireyin doğadaki yalnızlığında gizliydi” diye tanımlamaktadır. Fotoğraflarındaki renklendirme ve grafik düzenlemeler farklı sanat disiplinleri ile kurulan iletişimin göstergeleridir. Ün'ün 1994-2000 yılları arasında gerçekleştirdiği kolaj, fotomontaj, kart boyama (pastel, guaj, ekolin, yağlı boya) ve kazıma tekniklerini kullanarak oluşturduğu 'Yüzler ve Düşler' (1995) serisi, sanatçının dostlarını görsel açıdan tanımlamasıdır. 'Seyretmek' (1996) serisi, $8 \times 8 \mathrm{~cm}$. polaroidlerin emülsiyonlarına yapılan müdahaleler, soyut ve sembolik anlatımı ile dikkat çekmektedir. 'Hiçlik ve Kimlik' (Nihility or Identity) (2000) Tahir Ün tarafından "bir bunalım projesi” olarak tanımlanmaktadır. Proje, "Toplumsal açıdan küreselleşme olgusunun ağırlığını hissettirmesiyle birlikte, dinsel, cinsel, ekonomik ve politik sorgulamalarının son derece yoğunlaştığı bir sürecin sonucudur" (Ün, 2009).

Orhan Cem Çetin'in (1960), İstanbul Refo Fotoğraf

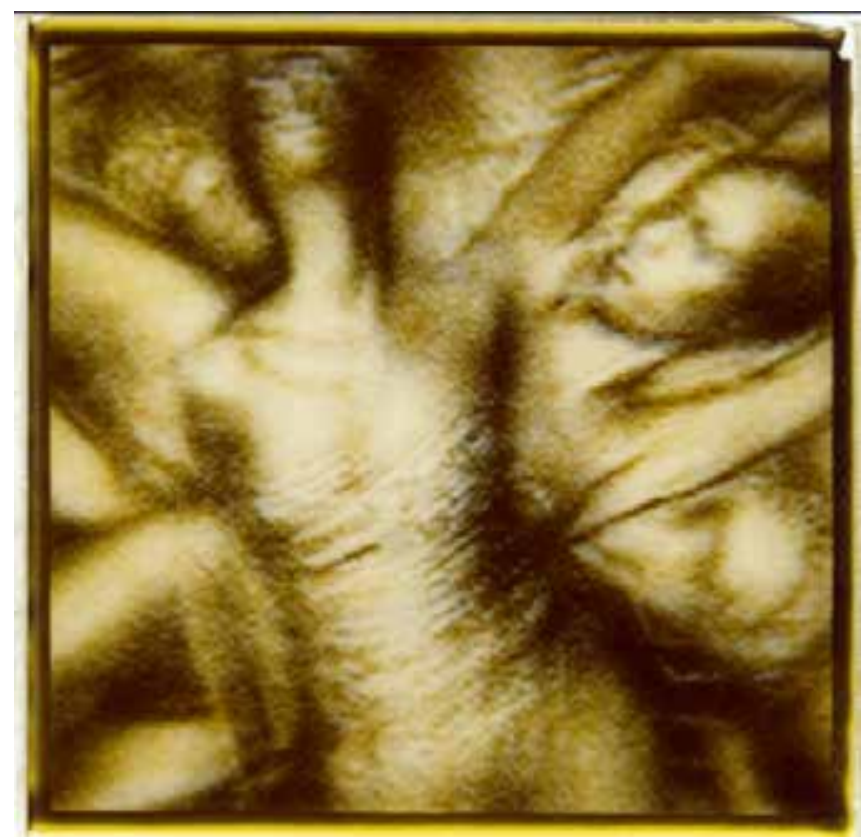

Fotoğraf 3. Tahir ün, 'Seyretmek', 1996

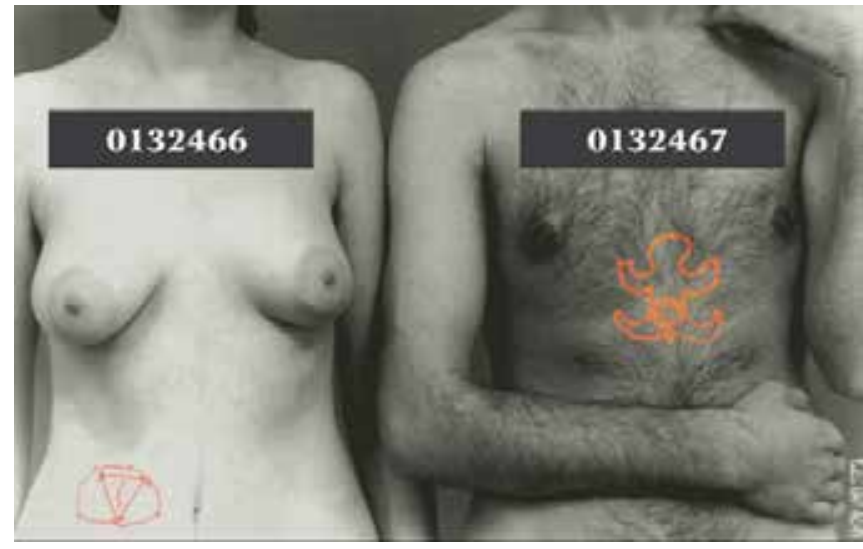

Fotoğraf 4. Tahir Ün, ‘Hiçlik Kimlik', 1997.

Galerisi'nde 1988'de açtığı 'Tanıdık Şeyler' sergisi, karanlık odada kendi geliştirdiği yöntemlerle renklendirdiği soyutlama ve grafik özellikleriyle ön plana çıkan fotoğraflardan oluşmaktadır. Çetin (2010), yöntemini şöyle tanımlamaktadır: "Bu fotoğraflar, bire bir boyutta kâğıt negatiflerden elde edilmiş renkli kontakt baskılardır. Tamamı elle renklendirilmiştir. Ancak, renklendirme siyah beyaz kâğıt negatif üzerinde, negatif renklerle guaj ya da kuru boyalar gibi örtücü olmayan, mürekkep benzeri, sıvı saydam boyalarla (örneğin ekolin) yapılmıştır. Sonuçta elde edilen baskı renkli fotoğraf kâğıdı üzerindedir ve herhangi bir boya taşımamaktadır. Kâğıt negatifler, agrandizörde $35 \mathrm{~mm}$ dia- 
ların $18 \times 24 \mathrm{~cm}$. boyutlarında Ilford Multigrade siyah beyaz kâğıtlara pozlanmasıyla elde edilmiştir.”. Çetin'in döneminin ruhunu yansıtan ve yeni yöntemler sunan deneysel çalışması, karanlık odada yoğun emek gerektiren tekniği sebebiyle başka fotoğrafçılar tarafından denenmemiştir.

Fotoğrafa 1980’lerde AFSAD'da başlayan Ahmet Selim Sabuncu (1962), deneysel çalışmalarında fotoğraf boyama tekniklerine ağırlık vermiş ve çeşitli sergilerde yer almıştır. Sabuncu'nun ‘Boyalı Fotoğraflar' sergisi, Ankara Dost Kitabevi Sanat Galerisi'nde 1995 yılında açılmıştır. Sabuncu'nun TRT'de hazırladığı 'Türk Fotoğraf Sanatı' belgeseli (1991) kapsamında, Şahin Kaygun'un verdiği boyama tekniğine ait detaylarla zenginleşen fotoğraflardan oluşan sergi, ustaya saygı niteliğindedir ve bu alandaki çalışmaların son örneği olmuştur (Sabuncu: 2015). Kolaj, fotomontaj ve düzenlemelerden oluşan fotoğraflar, özgün yorumları ile disiplinler arası okumalara imkan vermektedir.

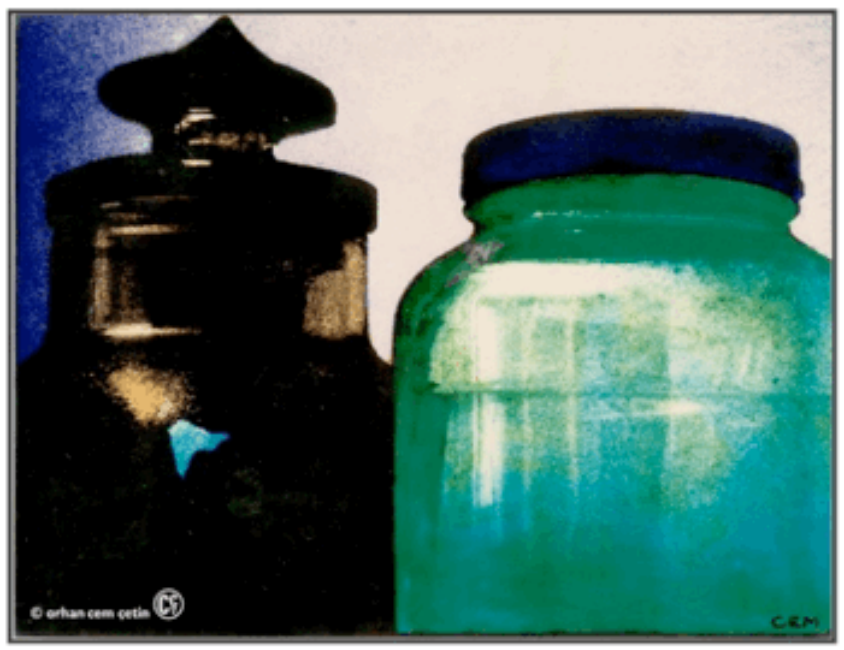

Fotoğraf 5. Orhan Cem Çetin, ‘Tanıdık Şeyler’,1988

Ahmet Öner Gezgin (1948), 1970 yılında Dekoratif Sanatlar Tekstil Dizayn dalından mezun olmuş, 1972'de devlet bursu ile gittiği Almanya Kassel Üniversitesi Güzel Sanatlar Akademisi'nde ‘Deneysel ve Renkli Fotoğraf' ve 'Grafik Tasarım’ eğitimini 1977 yılında tamamlamıştır. 1978’de İstanbul Devlet Güzel Sanatlar Akademisi'nde asistan olarak akademik göreve başlamıştır (ahmetonergezgin.com).

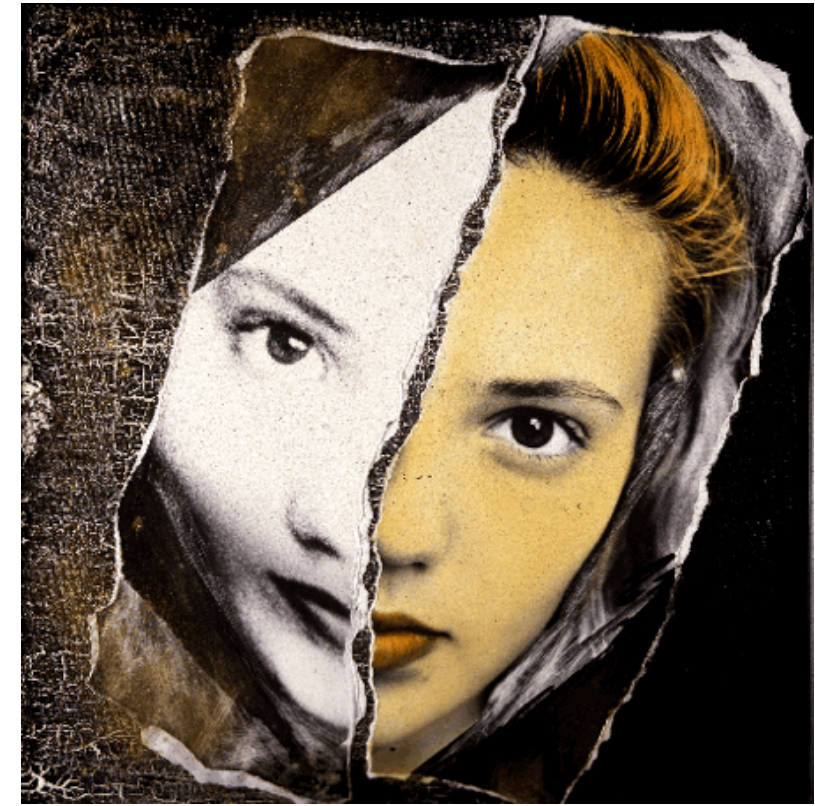

Fotoğraf 6. Ahmet Selim Sabuncu, ‘Boyalı Fotoğraflar’,1995

1981 Avusturya Salzburg Güzel Sanatlar Uluslararası Yaz Akademisi'ne katılmıştır. Gezgin, “ben 'an'ı’ fotoğraflamak yerine izlemeyi, ... düş gücümü ve bilinçaltımı harekete geçirerek... kendi öznel gerçekliğimi yaratmayı tercih etmişimdir... her zaman" (Ertan, 2005: 54) diyerek fotoğraf anlayışını tanımlamaktadır. Tasarladığı fotomontajlarında doğa algısı, insan doğa ilişkisi, insan kimliği, evrensel duygu kalıpları ön plandadır. 1985-1988 yıllarında gerçekleştirdiği fotomontajlarında çıplak kadın bedenleri ile kurduğu anlam dizgesi, Türk fotoğrafında en çok tekrarlanan kalıplara dönüşmüştür.

Dönemin en çok tanınan fotoğrafçılarından biri olan Nuri Bilge Ceylan (1959), 1975 yılında fotoğrafa başlamıştır; Boğaziçi Üniversitesi Elektrik Mühendisliği Bölümü mezunudur (www.nuribilgeceylan.com). 1995 yılından itibaren yönettiği filmlerle uluslararası üne kavuşan sanatçının 1982-1989 dönemi fotoğrafları Türk fotoğrafında önemli bir yere sahiptir. İncelikli siyah beyaz baskılarında solarizasyon, tonlama, fotomontaj tekniklerini kullanmıştır. Yalın komposizyonlu fotoğraflarında kadın - erkek ilişkisi, özlem, yalnızlık, özgürlük duyguları kurgulanmıştır. Ceylan'ın anlatım dili, amatör, profesyonel pek çok fotoğrafçıya rehber olmuştur. 


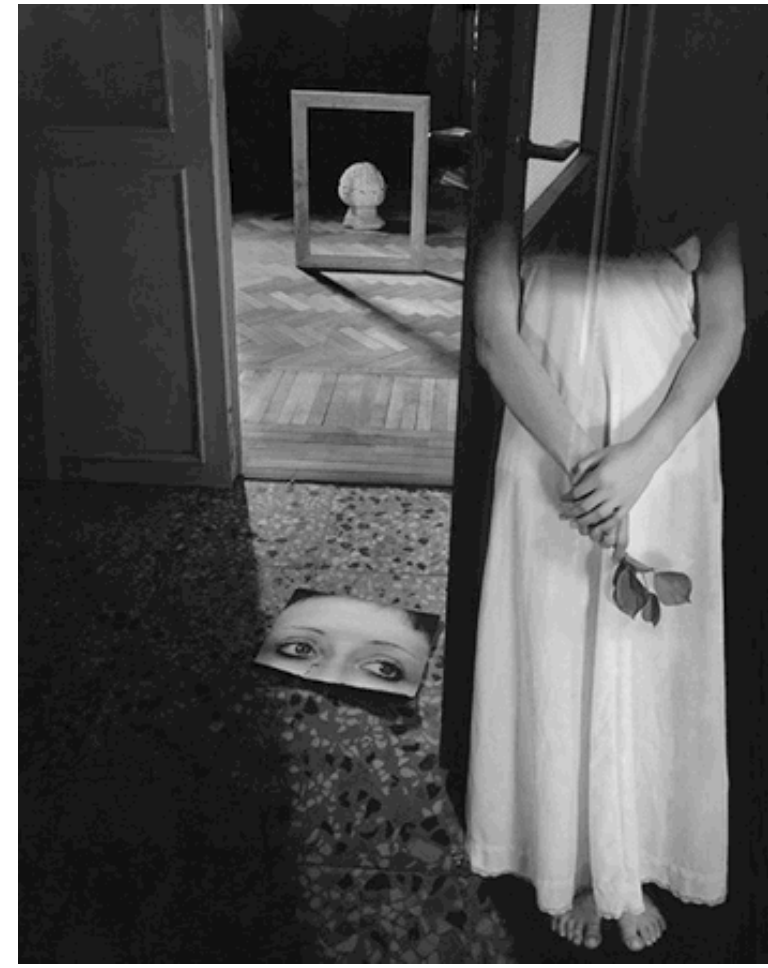

Fotoğraf 7. Ahmet Öner Gezgin,1979

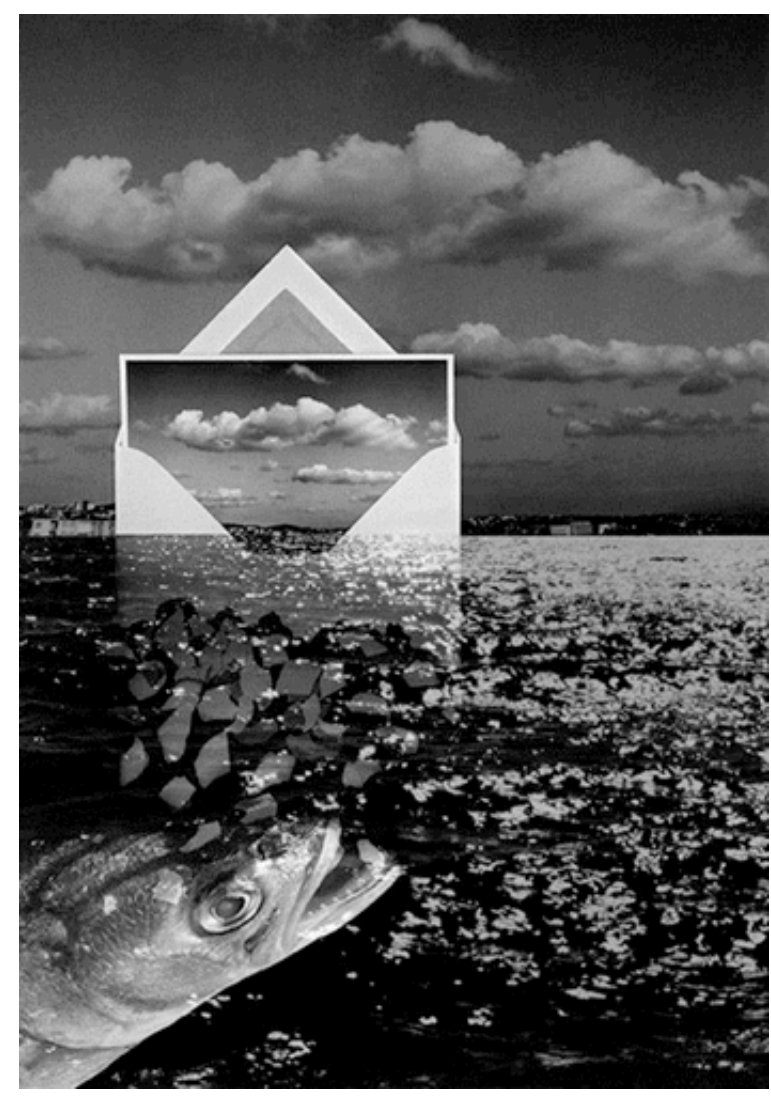

Fotoğraf 8. Ahmet Öner Gezgin,1984
Kurgu fotoğrafı vizyonuna temel alan isimlerden bir de Orhan Alptürk'tür (1953). 1982-1990 dönemine ait fotoğraflarını topladığı '40 Öykü’ albümünde yer alan sade komposizyonlarında grenli baskılar, kontrastlıklar ön plandadır. Alptürk çalışmalarında "bireyi, insanın yalnızlığını, iletişimsizliğini, bireyin toplum içindeki yerini sorguladığını" belirtmektedir (Alptürk, 1990).

Ahmet Öner Gezgin'in öncü vizyonu ve onu izleyen Nuri Bilge Ceylan, Orhan Alptürk'ün fotoğraflarında örneklendirdiğimiz daha çok sahneleme, öykülendirme ve fotografik ifade biçimi, derneklerde faaliyet gösteren amatör fotoğrafçılar tarafından en fazla tekrarlanan vizyonlar olmuştur. Bu fotoğrafları genel olarak değerlendirdiğimizde, sınırlı sayıda ve biçimsel tekrarlara dayanmakta oldukları görülür.

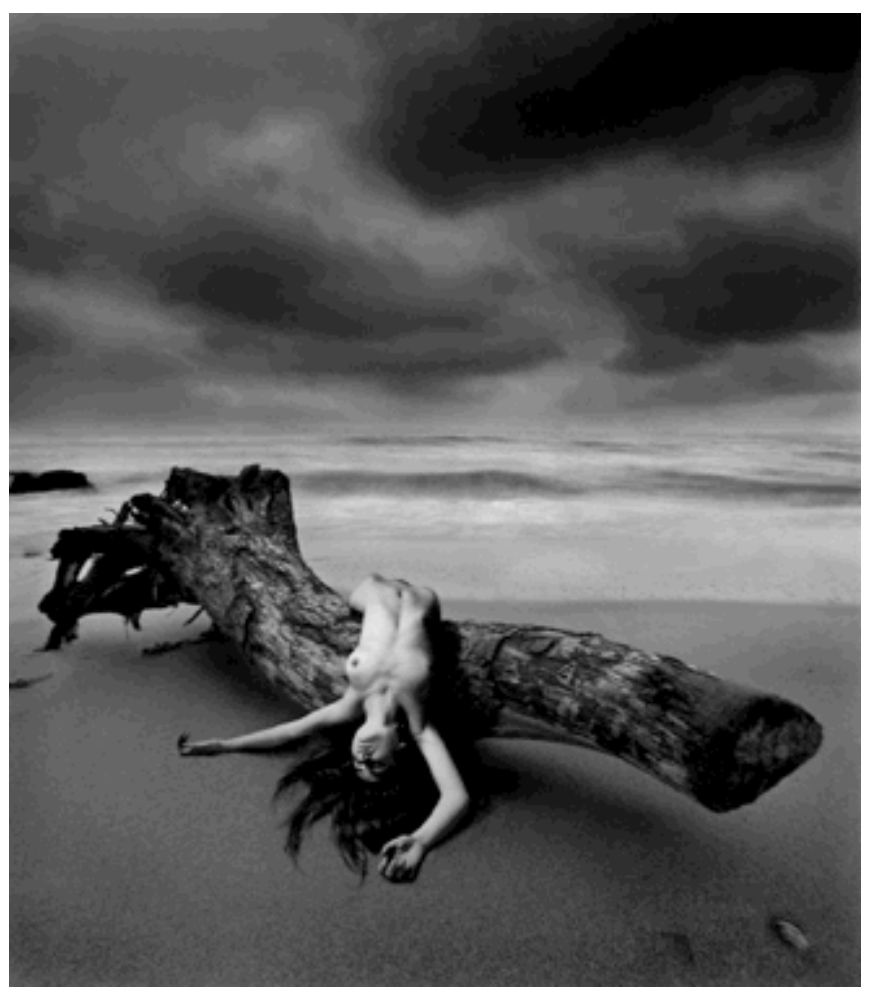

Fotoğraf 9. Nuri Bilge Ceylan

Nazif Topçuoğlu (1953), 1990 yılındaki 'Sebzeli Natürmort' ve 'Sebzeli Kızlar' (http://naziftopcuoglu.com) çalışmalarında 'still-life' üzerinde kurguladığı kompozisyonlarda resim ve edebiyat disiplinlerine yaptığı göndermeler, yetkin ışık kullanımı ve sembolik anlatımı ile yeni bir bakış açısı sunmuştur. Topçuoğlu, fotoğrafa bakışını 


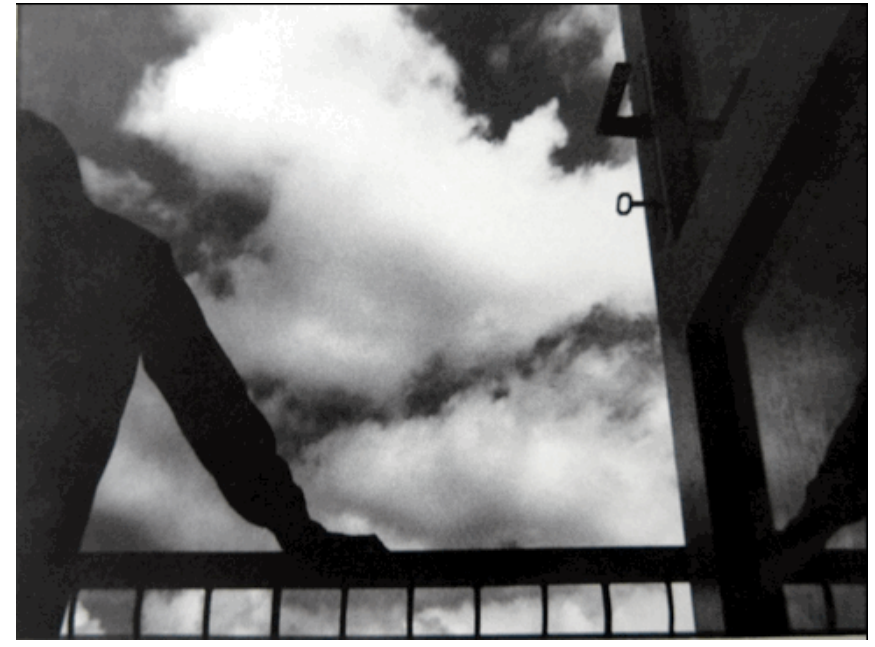

Fotoğraf 10. Orhan Alptürk, ‘40 Öykü’,

"Bir şeyi yakalamak değil, bir şeyi inşa etmek ve onu fotoğraflamak” şeklinde belirtmektedir (Geniş Açı, 2001: 24). Topçuoğlu'nun vizyonu, dönemin deneysel/kurgu anlatım tarzının stüdyo ortamında gerçekleştirilen boyutudur, ancak ardılları olmamıştır.

\section{Sonuç}

Makale kapsamında, Türk fotoğrafında 1980-1995 döneminde etkili olan, fotoğrafa karanlık odada yapılan müdahalelerle şekillenen deneysel ve görüntünün tasarlanarak oluşturulduğu kurgusal-yaratıcı fotoğraf ifade biçimleri, örnekler çerçevesinde tanımlanmıştır. Bu tanımlama yapılırken geleneksel karanlık oda teknikleri ile yaratılan vizyonlar temel alınmıştır.1995 sonrası yaygınlaşan dijital teknoloji ile oluşturulan vizyonlar ayrı bir araştırma konusudur.

Çalışma kapsamında taranan dergi, yayın, porfolyo vb. sınırlı kaynaklar ışığında 1965-1980 sürecinde amatör ya da profesyonel, fotoğrafla ilgilenen kişilerin, fotoğrafın dernekleşmesi, üniversitelerde bölüm olarak kurulması, dergicilik vb. pek çok alanda özveri ve elbirliği ile çalıştığı saptanmıştır.

1980'li yıllarda Şahin Kaygun ve Ahmet Öner Gezgin yurt dışında aldıkları eğitimler sonucu vizyonlarını geliştirmişlerdir. Kurgu çalışmalarında bireysel dışavurum aracı olarak fotoğrafı ve karanlık oda müdahale yöntemlerini kullanmışlardır. Batı fotoğraf kültürü ve görüntü üretim teknikleri ile üretilen bu fotoğraflar, yarattıkları tartışma ortamı ile Türk fotoğrafında modernizm sürecini başlatmıştır.
$\mathrm{Bu}$ süreci belirleyen çalışmalar incelendiğinde, Şahin Kaygun'un fotoğraflarında, karanlık oda tekniklerinin içeriğin vurgulanmasında ve estetik sınırların belirlenmesinde temel olduğu görülmüştür. Kaygun'un çalışmaları teknik nitelikleri bakımından modernist bir tavır sergiler, kurgularında yer alan görseller sembolik anlamlara sahiptir. Sanatçının fotoğraflarında etkin olan disiplinler arası göstergeler/göndermeler, post-modernizm kapsamında karşılığını bulur. Şahin Kaygun'un çalışmalarını referans alan sanatçıların yapıtlarında da aynı özellikleri görmek mümkündür.

Ahmet Öner Gezgin'in kurgu fotoğraflarında fotomontaj temel alınmıştır. Gezgin'in fotomontajlarında doğa algısı, kimlik bunalımları vb. temalar sembolik bir dille anlatılmıştır.

Kaygun ve Gezgin'in vizyonlarını referans alarak amatör fotoğrafçılar tarafından üretilen fotoğraflarda, tema olarak kadın/erkek ilişkisi, ayrılık, sevgi, özlem, özgürlük vb. duygular ağırlıklıdır. Bu duyguların karşılığı olarak beyaz güvercin, parmaklık, çerçeve, çerçeveden çıkan kuşlar, deniz kıyısı, kayık, balık, bulut, çiçek demetleri en fazla tekrarlanan şablon görseller olmuştur.

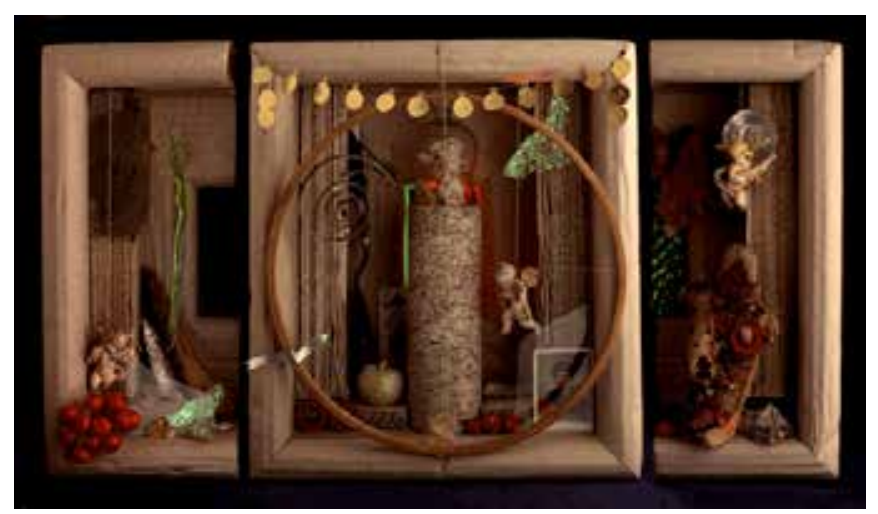

Fotoğraf 11. Nazif Topçuoğlu,1990, 


\section{Kaynakça}

Ak, Seyit Ali, (1989) “Fotoğrafçılığımız” Refo Fotoğraf Sanatı Dergisi, sayı: 11 ,

Alptürk, Orhan, (1990), 40 Öykü, Ankara: Pelin Ofset.

Duben, İpek; Yıldız Esra (2008), Seksenlerde Türkiye'de Çağdaş Sanat: Yeni Açılımlar, İstanbul: İstanbul Üniversitesi Yayınları.

Erik Jan, Zürcher, (1996) Modernleşen Türkiye’nin Tarihi, çev. Yasemin Saner Gönen, İstanbul: İletişim Yayınları.

Ertan, Güler, (1977), Çağdaş Fotoğraf Sanatı, İstanbul: Sayılı Matbaa.

Ertan, Güler, (2005), Türk Fotoğrafında 1960 Sonrası, İstanbul: Bileşim Yayınları.

Ertuğ, Tekin, (2013), Fotoğraf Ustaları 4, Ankara: (FSK)Fotoğraf sanatı Kitapları.

Oktay, Emre, "12 Eylül Liberalizm ve Sanat”, Yeni Tiyatro Dergisi, 25 Ekim 2012

Özdal, Işık, (2009), “Engin Çizgen” Kadın Fotoğrafçılarla Fotoğraf Üzerine”, İzmir: Koyu Kitap.

Topçuoğlu, Nazif (2001), “Genç Kızlar Ölüm ve de Goblin” Geniş Açı Fotoğraf Sanatı Dergisi, İstanbul

Ün, Tahir, (1990) Imagined Views/Düşlenmiş Manzaralar, Ankara: Pelin Ofset.

Ün, Tahir, (1995), “Türkiye’ de Plastik Sanatların Değişen Boyutları İçerisinde Fotoğrafın Yeniden Değerlendirilmesi”, Fotoğraf Sanatının Plastik Sanatlar İçindeki Yeri, Panel'de sunulmuştur - Türk İngiliz kültür Derneği, Ankara.

Yeni Fotoğraf, Haziran (1977), Sayı:9, İstanbul: Erler Matbaası

Yeni Fotoğraf, Mart (1977), Sayı:6, İstanbul: Erler Matbaası

Zeyrek, Şerafettin, (2006), Türkiye'de Halk Evleri ve Odaları, Ankara: Anı Yay.

\section{Internet Kaynakları}

Ceylan, Nuri Bilge, http://www.nuribilgeceylan.com/(Erişim Tarihi:03.05.2015)

Madra, Beral, “Geriye de Bakmalı Değil mi 80’li yıllarda Türkiye'de Sanat,80'li yıllarda Türkiye'de Sanat üretimi” http://www.beralmadra.net/exhibitions/abalance-retrospective-of-the-80s-in-turkey/ (Erişim Tarihi: 15.05.2015)

Çetin, Orhan Cem, "İzahlı Orhan Cem Çetin Külliyatı”, http://fotografya.fotografya.gen.tr/issue-14/occ_14_ index.htm (Erişim Tarihi: 09.04.2015)
Dural, Tevfik Çağrı - Soysal, Şener, (2015), "Bir Şahin Kaygun Araştırmasından Soru(n)lar”, ortaformat.org/ articles/13_bir-sahin-kaygun-arastirmasindansorunlar/ (Erişim Tarihi:06.04.2015)

Gezgin, Ahmet Öner, http://www.arsivfotoritim.com/yazi/ahmetoner-gezgin-fotografi/ (Erişim Tarihi: 03.05.2015)

Kaygun, Şahin, www.fotograf.net/Artist/sahinkaygun Devlet tatbiki Güzel Sanatlar,http://www.msgsu.edu.tr/trTR/ tarihce/123/Page.aspxtp:// (Erişim Tarihi:11.05.2015)

İstanbul Bilgi Üniversitesi Yayınları, İstanbul (ErişimTarihi:15.05.2015)

Fotoğraf dergisi, (1984 Ocak), S:14, Ankara: Afsad Yayınları. Fotoğraf Dergisi, (1984 Aralık), sayı: 23, Ankara: Afsad Yayınları. Topçuoğlu, Nazif, http://naziftopcuoglu.com/ (Erişim Tarihi: 04.03.2015)

Ün, Tahir, (1-6 Şubat 2009) "Sadece Biraz Daha Özgürlük", Fotoritim http://www.fotoritim.com (Erişim Tarihi:04.02.2009)

Ün,Tahir, http://www.tahirun.com/, (Erişim Tarihi:10-12-20015) Eczacıbaşı Renkli Fotoğraf Yıllıkları, (2010 Şubat), Fotoritim E-Dergi http://www.arsivfotoritim.com/ yazi/2010/02/page/3/ (Erişim Tarihi: 29.03.2015) ( http://www.tfsf.org.tr)

\section{Röportajlar}

Tahir Ün ile Röportaj 12 Mart 2015

Ahmet Selim Sabuncu ile Röportaj 08 Nisan 2015

\section{Görsel Kaynaklar}

Fotoğraf.1 Şahin Kaygun, 1983 (İstanbul Modern Katolog, 2015: 26).

Fotoğraf 2. Şahin Kaygun, ‘Genç Bir kadının Günlüğünden’, 1984 (İstanbul Modern Katolog,2015:84)

Fotoğraf 3. Tahir ün, 'Seyretmek', 1996 (Sanatçı Arşivi)

Fotoğraf 4. Tahir Ün, 'Hiçlik Kimlik', 1997(Sanatçı Arşivi)

Fotoğraf 5. Orhan Cem Çetin, 'Tanıdık Şeyler’,1988 (fotografya. gen.tr sayı:14 (Erişim Tarihi: 05.06.2015)

Fotoğraf6.AhmetSelimSabuncu, ‘BoyalıFotoğraflar’,1995,(Sanatçı Arşivi)

Fotoğraf 7. Ahmet Öner Gezgin,1979, http://www.arsivfotoritim. com/yazi/ahmet-oner-gezgin-fotografi/ (Erişim Tarihi: 03.06.2015)

Fotoğraf 8. Ahmet Öner Gezgin,1984, http://www.arsivfotoritim. com/yazi/ahmet-oner-gezgin-fotografi/ (Erişim Tarihi: 03.06.2015) 
Fotoğraf 9. Nuri Bilge Ceylan, http://www.nuribilgeceylan.com. (Erişim Tarihi:01.05.2015)

Fotoğraf 10. Orhan Alptürk, '40 Öykü’, (Alptürk,1990:24

Fotoğraf 11. Nazif Topçuoğlu,1990 http://naziftopcuoglu.com/ (Erişim Tarihi: 02.05.2015) 